\title{
A Note on the Debate over Renminbi Undervaluation*
}

\author{
Yin-Wong Cheung \\ Menzie D. Chinn \\ Eiji Fujii
}

In: Asia and China in the Global Economy, edited by Yin-Wong Cheung and Guonan Ma (World Scientific, 2011).

\section{Address for correspondence:}

Yin-Wong Cheung, Department of Economics, University of California, Santa Cruz, CA 95064, USA. Tel/Fax: +1 (831) 459-4247. Email: cheung@ucsc.edu.

Menzie D. Chinn, Robert M. LaFollette School of Public Affairs and Department of Economics, University of Wisconsin, and NBER, 1180 Observatory Drive, Madison, WI 53706, USA. Tel/Fax: +1 (608) 262-7397/2033. Email: mchinn@lafollette.wisc.edu.

Eiji Fujii, School of Economics, Kwansei Gakuin University, 1-155 Uegahara-1bancho, Nishinomiya, Hyogo 662-8501, JAPAN. Tel: +81 (798) 54-7257. Fax: +81 (798) 51-0944. E-mail: efujii@kwansei.ac.jp. 


\begin{abstract}
China's currency, the renminbi (RMB), has occupied a central role in the debate over the sources of global imbalances. As policymakers around the globe seek to establish the foundation for a sustained recovery from the world's most serious financial crisis in over seventy years, the pressure on the Chinese currency regime continues to mount. Nevertheless, there appears little consensus regarding the extent to which the RMB is actually undervalued despite the fact that the issue has been intensely contested for several years. In reviewing the debate, the current paper points to some pitfalls of assessing the extent of the RMB misalignment. In addition, we elucidate the sources of disagreements while updating the misalignment estimates by exploiting the latest set of data.
\end{abstract}

Key words: absolute purchasing power parity, China, currency misalignment, exchange rates, real income. 


\section{Introduction}

In the last Economic Report of the President of the Bush Administration, the excessive leverage and over-borrowing in the American economy at the heart of the ongoing financial and economic crisis were blamed on squarely on global imbalances, namely the large current account deficit of the United States and the equally large surpluses of the East Asian economies. In this argument, the role of the Chinese currency, the renminbi (RMB), takes a central role.

Regardless of the merits of this argument ${ }^{1}$, there is a renewed round of pressure on China to change her foreign exchange policy and revalue RMB when American and European policymakers seek to sustain the recovery from the crisis by all possible means. For instance, in a written submission to the Senate Finance Committee, Treasury Secretary Geithner stated that the Obama Administration "believes that China is manipulating its currency". ${ }^{2}$ Similarly, Dominique Strauss-Kahn, the managing director of the International Monetary Fund, recently reiterated his belief that the Chinese currency is significantly undervalued. ${ }^{3}$ Beijing responds to these and other claims by emphasizing China's role and contribution in stabilizing the global market economy. Along with some developing countries, China has expressed concerns about the highly accommodative nature of US monetary policy, the perceived policy of debasing the US dollar, and the adverse implications for the role of the US dollar as an international reserve currency. In this regard, the tone of the debate over the RMB has seen little change since the pre-July 2005 reform period. ${ }^{4}$

Indeed, the intense debate taking place over the past several years has produced little consensus among professionals and scholars regarding the extent to which the Chinese currency is actually undervalued, as well as the relative importance of currency misalignment to the extent of global imbalances. ${ }^{5}$ In a series of papers, Cheung et al. (2007, 2009a, 2009b) point to some 
critical issues surrounding the debate over the RMB misalignment. Specifically, they focus on the difficulty in measuring the "equilibrium real exchange rate" and highlight the uncertainty intrinsic to the commonly used measurement of the RMB misalignment.

In the current study, we take up the task of elucidating the sources of disagreements while updating the misalignment estimates based on the latest available data. The main issues of concern relate to the choice of modeling approaches, the impact of data uncertainty, and the selection of econometric methods.

The remainder of the paper is organized as follows. Section 2 discusses alternative approaches to estimating the equilibrium exchange rate. In particular, the merits and limitations of the real exchange rate-per capita income relationship approach are highlighted in comparison to other approaches. By exploiting the latest version of the data, Section 3 updates the RMB misalignment estimates. Implications of the recent substantial data revision are discussed. Section 4 focuses on some econometric issues that can significantly affect the inferences on the extent of the RMB misalignment. In Section 5, we extend our estimates by augmenting the baseline model with additional control variables. In particular, the role of trade imbalances is examined. Section 6 provides some concluding remarks.

\section{Alternative Approaches to Modeling the Equilibrium Exchange Rate}

\subsection{Conceptual differences and some practical issues}

At the heart of the debate over the appropriate exchange rate level are contrasting ideas of what constitutes an equilibrium exchange rate, what time frame the equilibrium condition pertains to, and, not the least, what econometric method to implement. ${ }^{6}$ Some short cuts have been used so often that it is sometimes forgotten that they are short cuts. 
As reviewed by Cheung et al. (2009a), most of the extant studies on the RMB misalignment fall into familiar categories, either relying upon some form of relative purchasing power parity (PPP) or cost competitiveness calculation, the modeling of deviations from absolute PPP, a composite model incorporating several channels of effects (sometimes called behavioral equilibrium exchange rate models), or flow equilibrium models. Table 1 provides a typology of these approaches, further disaggregated by data dimension including cross sectional, time series, and panel data.

In appraising the alternative approaches, we note that a useful model has to be able to inform us on how the Chinese current exchange rate stands relative to others, and not only relative to its own past. In other words, those that rely upon price indices, rather than actual price levels, are not informative for current purposes. Consequently, the models based upon relative PPP are not suitable. Neither are many of the behavioral equilibrium exchange rate (BEER) models as they also typically rely upon price indices. ${ }^{7}$ To highlight the drawbacks of using price indices, we examine briefly below what the oft-used relative PPP approach suggests about the RMB.

Figure 1 depicts the official exchange rate series from January 1987 to September 2009, deflated by the US and Chinese consumer price indices. The rate is expressed so higher values mean a stronger Chinese currency (the units of currency are denoted as CNY, for Chinese Yuan). The solid black line gives the official real exchange rate and the dashed line gives the "adjusted" real exchange rate, which is defined later. In line with expectations, in the years since the East Asian crisis, the RMB has experienced a downward decline in value.

[Take in Figure 1 about here]

However, as with the case with many economies experiencing transitions from controlled 
to partially decontrolled capital accounts and from dual to unified exchange rate regimes, there is some dispute over what exchange rate measure to use. It turns out that in the years leading up to 1994, increasingly large amounts of RMB transactions were taking place at "swap rates" - rather than the official rate - so that the 1994 "mega-devaluation" is actually better described as a unification of different rates of exchange (Fernald et al., 1999). The “adjusted” rate in Figure 1 is a weighted average of the official and swap rates.

The problem with real exchange rates based on price indexes is that it provides no information on the level of the equilibrium rate and, thus, is difficult to determine the extent of currency misalignment. In the early warning system literature that developed in the wake of the financial crises of the 1990's, a typical measure of currency misalignment was the deviation from a deterministic trend. The linear trends fitted to the official and "adjusted" exchange rates are indicated, respectively, by the broken line and dotted line in Figure 1. According to this measure of misalignment, the "adjusted" displays an overvaluation of $10.4 \%$ and the official rate an overvaluation of $16.8 \%$ in September of 2009.

As a matter of principal, trade weighted rates are to be preferred to bilateral rates since the reliance on the latter can lead to misleading inferences about overall competitiveness. Replacing the bilateral exchange rates with the trade weighted rate does not necessarily clarify matters. Figure 2 depicts the IMF's trade weighted effective exchange rate index, and a fitted linear trend. One finds that focusing on the deviations from a simple trend indicates the RMB is $35.3 \%$ overvalued. Of course, a quick glance at the data indicates that a simple trend is an overly simple a characterization. Suppose instead that one assumed that the relevant period was 1987 onward; then a flat trend and zero misalignment would be the determination. The fact that working with simple straight line extrapolations can lead to such diverging conclusions suggests 
that we need to take a closer look at where the Chinese currency should stand, both over time and across countries.

\section{[Take in Figure 2 about here]}

Setting aside the approaches relying upon price indices, there are still more than one ways to model the “equilibrium real exchange rates”. In particular, one can take either a direct or indirect approach to estimating real exchange rate levels. A direct approach should model the level of China's real exchange rate, and estimate the extent of deviations of the actual rate from the equilibrium. Alternatively, one might pursue an indirect approach by focusing, for instance, on external balances to draw calculations upon implied extents of currency misalignment. Each approach has its own merits and drawbacks.

One example of the indirect approach is to focus on flow equilibria, considering savings and investment behavior and the resulting implied current account. The equilibrium exchange rate is then derived from the implied medium term current account using elasticities of imports and exports. A major obstacle to this approach is the fact that estimating the trade elasticities for China by itself poses a significant challenge. Specifically, it suffers from the absence of relevant price data on the Chinese imports and exports. ${ }^{8}$ Furthermore, given the rapid pace of structural transformation taking place in China, extending the sample period backward will not obtain relevant estimates. The reliability of the misalignment estimates, however, crucially hinges on the accuracy of the trade estimates. Wang (2004), for instance, discusses the difficulties in using the flow equilibrium approach for China.

Another strand of literature infers the extent of currency misalignment by focusing on a discrepancy between normal capital flows and the underlying current account position (Bosworth, 2004; Goldstein, 2004; Goldstein and Lardy, 2006). This approach is perhaps most useful for 
conducting short- to medium-term analyses and is driven by a presumption of what is the sustainable current account balance for a typical developing country. However, the wide dispersion of implied misalignment estimates reflects the difficulty in making judgments about what constitutes persistent capital flows and what is the sustainable current account balance. For instance, Prasad and Wei (2005), examining the composition of capital inflows into and out of China, argue that much of the reserve accumulation that has occurred in recent years is due to speculative inflow; hence, the degree of misalignment is small.

\subsection{The Real Exchange Rate- Per Capita Income Relationship Approach}

In view of the above alternatives, Cheung at al. (2007) opts for an approach that estimates directly deviations from the equilibrium real exchange rate. Specifically, they exploit the well-known empirical positive relationship between real exchange rate and real per capita income level across countries.

The empirical positive relationship could be illustrated by decomposing national price levels into their nontradables and tradables components. Specifically, let the home country's goods basket be composed of nontradables and tradables with respective shares of $\alpha$ and $(1-\alpha)$. Then, the home country general price level, in log, is written as:

$$
p_{t}=\alpha p_{N, t}+(1-\alpha) p_{T, t}
$$

where $p_{N, t}$ and $p_{T, t}$, respectively, denote the prices of nontradables and tradables in log terms. Assume that the price level of a foreign country is defined with the same weight $\alpha$, and let $s_{t}$ be the log nominal exchange rate measured in units of home currency per foreign currency. Then, the price level of the foreign country relative to that of the home, or the real exchange rate, is given by

$$
q_{t} \equiv s_{t}+p_{t}^{*}-p_{t}=\left(s_{t}+p_{T, t}^{*}-p_{T, t}\right)+\alpha\left[\left(p_{N, t}^{*}-p_{T, t}^{*}\right)-\left(p_{N, t}-p_{T, t}\right)\right]
$$


The first term in parentheses is the intercountry price of tradables, while the second term in the square brackets gauges the intercountry relative price of nontradables to tradables. Thus, the expression indicates that the real exchange rate can fluctuate as changes occur in the relative price of traded goods between countries, or as the relative price of nontradables rises in one country, relative to another. In principle, economic factors can affect one or both.

It is known that the law of one price does not necessarily imply absolute purchasing power parity if the home and foreign countries have different $\alpha$ 's. The "price level" variable in the Penn World Table and purchasing power parity exchange rates circumvent this problem by using prices of identically specified goods and the same weights to calculate the aggregate price level (Summers and Heston, 1991). Thus, price and income variables derived from the Penn World Table methodology are used in the subsequent empirical analyses,

The sectoral-productivity-based models, pioneered by Balassa (1964) and Samuelson (1964), typically assume the law of one price for tradables in (2), and conjecture that the relative sectoral productivity differentials determine the real exchange rate via the relative nontradable prices. This perspective provides the key rationale for the well-known positive cross-sectional relationship between real exchange rate and relative per capita income levels. ${ }^{9}$ Since Balassa (1964) that uses per capita income as a proxy for productivity, a plethora of studies have estimated variants of (2) and found statistically significant positive association between price and per capita income levels. ${ }^{10}$

By placing the RMB in the context of this well-established empirical relationship exhibited by a large number of developing and developed countries, over a long time horizon, one can address the question of where China's real exchange rate stands relative to the “equilibrium” level. For instance, Bosworth (2004), Frankel (2006), Coudert and Couharde 
(2007), and Cairns (2005) examine the real exchange rate-per capita income relationship and report similar results regarding the positive association between the two variables. ${ }^{11}$ Cheung et al. (2007) extends the approach along several dimensions. First, they adopt a panel framework to augment the preceding cross-sectional studies by incorporating the time series dimension. Second, they explicitly characterize the uncertainty surrounding the determination of currency misalignment. That is, in addition to the magnitude of a coefficient estimate, which could be used to assess its economic significance, they consider statistical significance that the profession usually uses to assess the reliability of the estimation result. Third, they examine the stability of the relationship between real exchange rate and relative per capita income using a) subsamples encompassing different country groups and different time periods, and b) control variables.

One point worth mentioning is that studies adopting the real exchange rate-per capita income relationship approach yield the largest estimated degree of RMB undervaluation (Cairns, 2005). Those implementing either the relative PPP or flow equilibrium approaches typically find smaller estimates of the extent of the RMB undervaluation. Thus, adopting the real exchange rate-per capita income relationship approach does not bias the results against RMB undervaluation.

It is important to acknowledge the limitations of the real exchange rate- per capita income relationship. Theoretically, the equilibrium exchange rate in the Balassa-Samuelson model is the one that is consistent with both internal and external balances. In the short- to medium-term, however, internal or external balance is not guaranteed. Thus, the estimated exchange rate measure is properly interpreted as a long-run measure and is ill-suited (on its own) to analyzing short run phenomena. One potential remedy is to include control variables that are relevant for (short-run) variations in internal and external balances. This remedy is explicitly 
considered in section $5 .^{12}$

\section{Misalignment Estimates - Old and New}

Using a data set comprising a maximum of 160 countries from 1975-2004, Cheung et al. (2007) estimates the equation

$$
q_{i, t}=\beta_{0}+\beta_{1} y_{i, t}+u_{i, t},
$$

where $q_{i, t}$ and $y_{i, t}$ are, respectively, country i's price level and per capita income relative to the US ones in real term. The data are drawn from the World Bank's World Development Indicators (WDI).

Figure 3, reproduced from Cheung et al. (2007), plots the actual and predicted RMB real exchange rate and standard error bands derived from the 1975-2004 PPP-based income data. It is interesting to follow the path that the RMB has traced out in the graph. It begins the sample as overvalued, and over the next three decades it moves toward the predicted equilibrium value and then overshoots, so that, by 2004 , it is substantially undervalued - by $53 \%$ in level terms (greater in log terms). Importantly, however, in 2004 the RMB was more than one standard error-but less than two standard errors - away from the predicted value, which in the present context is interpreted as the "equilibrium” value. In other words, by the standard statistical criterion that applied economists commonly appeal to, the RMB is not undervalued (as of 2004) in a statistically significant sense. The wide dispersion of observations in the scatter plots should give pause to those who would make strong statements regarding the exact degree of misalignment. In view of Figure 3, some observers would suggest that the RMB will shortly go below the lower prediction error band and the undervaluation will be statistically significance with a magnitude of over $50 \%$. 
[Take in Figure 3 about here]

In 2008, however, the World Bank in cooperation with the Asian Development Bank reported new estimates of China's GDP and price level measured in PPP terms, which are based on new benchmark data on prices generated by the International Comparison Project. These new estimates effectively revise down, for example, the 2005 China's PPP-based per capita GDP (or revise up its PPP-based real exchange rate) by about $40 \%$ below (above) the previously reported figures. ${ }^{13}$ Taking proper account of this revision requires re-estimating the regressions because data for many countries were substantially revised as well.

While Cheung et al. (2009b) discusses the implications of data revision, the current paper further updates the analysis and provides new misalignment estimates derived from the latest available data. The new estimation results of (3) are summarized in Table 2. The use of either US dollar-based or PPP-based income data gives qualitatively similar results.

The actual and predicted rates are plotted in Figures 4 and 5. The magnitude of the change in the implied misalignment for the RMB is striking. Essentially, as of 2007, the estimated degree of undervaluation is about $10 \%$ in level terms, which represents a massive reduction in the extent of misalignment. The new undervaluation estimate for 2004 turns out to be around $18 \%$, only about one-third in magnitude of the old estimate of $53 \%$. The maximal undervaluation is identified in 1993. These figures suggest that our previous finding of substantial misalignment - in the order of $50 \%$ - is not robust to the data revision implemented by the World Bank.

\section{[Take in Figures 4 and 5 about here]}

In Figures 6 and 7, we show the time series path of the actual RMB rate, against its predicted value and corresponding two standard error bands. It is clear from these graphs that 
there is no statistically significant RMB misalignment. In fact, while being below the estimated equilibrium line, the RMB has never gone below the one standard error prediction band over the past two decades. In sum, the results based on the revised data suggest that the extent of the RMB undervaluation is modest and, in the statistical sense, indistinguishable from zero.

[Take in Figures 6 and 7 about here]

\section{Some Econometric Issues: Sampling Uncertainty and Serial Correlation}

\subsection{Sampling Uncertainty}

One of the key emphases of Cheung et al. (2007) is the role of sampling uncertainty in interpreting the estimated degree of misalignment. That is, in addition to estimating the economic magnitude of the implied misalignments, they emphasize the importance of taking the level of precision in assessing misalignment estimates. To this end, they presented both the estimated degree of misalignment and its sampling certainty given by its prediction error bands.

Some observers, while not necessarily disagreeing with the real exchange rate-per capita income relationship approach, have some concerns about the way Cheung et al. (2007) derived the misalignment sampling uncertainty; see, for example, Cline and Williamson (2008).

Cheung et al. (2007) followed the standard procedure to construct the prediction error confidence interval. The width of the interval is determined by two components; namely the variance of the regression error term ( $u_{i t}$ in (3)) and the variance of the coefficient estimators ( $\hat{\beta}_{0}$ and $\hat{\beta}_{1}$ in (3)). It is quite well known that, under standard assumptions, the coefficient

estimators, $\hat{\beta}_{0}$ and $\hat{\beta}_{1}$, are consistent and their variance decreases as the sample size increases - in technical jargon, their variance goes to zero asymptotically and does not contribute to the width of the prediction error confidence interval. However, the variance of the regression error 
term does not go to zero as the sample size increases.

Intuitively, the increase in observations helps reduce the uncertainty associated with the estimates of $\beta_{0}$ and $\beta_{1}$ but not the uncertainty of the regression equation itself as represented by the variance of $u_{i t}$. Unless we have a perfectly fitted regression, the variance of $u_{i t}$ will be non-zero. That is, for a given regression, we cannot predict perfectly; what we could do is to reduce the coefficient sampling uncertainty.

What happens when we compute the prediction error confidence interval using only information on the variance of the coefficient estimators as suggested by some studies? In such a case, the resulting interval gives only the range in which the regression line can lie, under a pre-specified confidence level and ignores the fact that the underlying regression is not an exact relationship between real exchange rates and real income levels. The interval over-states the ability to predict real exchange rates and, hence, the evidence of a significant misalignment. Thus, an appropriate procedure to construct the RMB prediction error confidence interval is crucial to making misalignment assessment; especially given the large data dispersion observed in Figures 4 and 5.

That said, how should the prediction error results in Figures 6 and 7 be interpreted? While the real exchange rate-income relationship is a robust empirical regularity (that is, the positive slope coefficient estimate is highly statistically significant), the data are not sufficiently informative enough to allow us to make sharp inferences about the extent to which the Chinese RMB is misaligned. We emphasize that, even though the result does not allow us to conclude there is undervaluation, it also means we cannot rule out RMB undervaluation. This is a point worth repeating since it is not always explicitly stated despite its importance. The problem we are facing is that the data and models in hand fail to distinguish a range of competing hypotheses 
regarding the extent of the RMB misalignment by the means of statistical tests. ${ }^{14}$

\subsection{Serial Correlation}

From Figures 4 and 5, we notice that the deviations from the conditional mean are persistent; that is, deviations from the real exchange rate - per capita income relationship identified by the regression are persistent, or exhibit serial correlation. Frankel (2006) makes a similar observation, noting that half of the deviation of the RMB from the 1990 conditional mean exists in 2000. The presence of persistent serial correlation in effect means that the number of observations in the sample overstates the number of independent data points, and, thus, sampling uncertainty is higher than it appears.

From a technical perspective, the presence of significant serial correlations leads to downward bias in the standard error of the regression. Specifically, the standard error of the regression needs to be adjusted upward by a factor equal to $\left[1 /\left(1-\rho^{2}\right)\right]^{0.5}$ for which $\rho$ is the autoregressive coefficient. We estimate $\hat{\rho}$ to be approximately 0.94 (derived from PPP-based per capita income figures) on an annual basis. Hence, a simple and ad hoc adjustment method requires the standard error of the regression to be multiplied by a factor of three to get reliable statistical inferences. An immediate consequence is to widen further the prediction error bands in Figures 6 and 7.

While the ad hoc adjustment procedure offers a more accurate assessment of the degree of uncertainty surrounding the predicted level of misalignment, it gives no information on the relative price-income relationship that is not distorted by serial correlation. Therefore, to obtain estimates that are statistically correct in the presence of serial correlation, we implement a panel version of the Prais-Winsten procedure. ${ }^{15}$ The results are reported in the third column of Table 2. 
The pooled OLS estimate using PPP-based per capita income indicates a short run elasticity of 0.15 , which is somewhat smaller than the coefficient estimate without the serial correlation adjustment. The autoregressive coefficient is estimated to be around 0.94. Relaxing the assumption that the errors are the same across time and individual countries (that is, the random effects regression), we obtain a smaller short-run elasticity of 0.14 . Since the Hausman test rejected the orthogonality condition, we also consider the fixed effects regression results. The resulting cross-country elasticity is 0.24 (that is the "between” effect), and the short run elasticity 0.10 .

Figures 8 and 9 show the predicted RMB exchange rate based upon the pooled OLS estimates. The consequence of removing serial correlation from regression is remarkable. First, for most of the sample period, the actual RMB value is within the one standard error prediction band - that is, the currency is insignificantly different from its predicted equilibrium value. The result is similar to the one depicted in Figures 6 and 7. Second, after the actual and predicted RMB values virtually collided with each other in 1993, the actual value has been slightly above the predicted one; suggesting a slight overvaluation albeit it is statistically insignificant. When explicitly adjusted for serial correlation, the estimates point to the possibility of RMB overvaluation in the recent years.

[Take in Figures 8 and 9 about here]

Nevertheless, one should not take the overvaluation results literally for the very same reason noted in the context of the undervaluation findings. The empirical results merely suggest that the case for overvaluation is as weak as the case for undervaluation. In other words, we have little certitude about RMB misalignment using this oft-used cross-country relationship between relative price and relative per capita income levels, once issues of serial correlation are explicitly 
accounted for. Despite the apparent RMB undervaluation by the means of point estimates in Figures 6 and 7, the adjustment for serial correlation effects results in a much weaker case for a significantly undervalued RMB. In the next section, we shift our attention to other factors that might alter the reported real exchange rate-per capita income relationship.

\section{Multivariate Extensions}

In section 2, we noted that the equilibrium exchange rate underlying the real exchange rate-per capita income relationship approach is the one consistent with both internal and external balances. These balances are unlikely to be observed, say, for China and other developing countries in the sample. Thus, to control for effects of imbalances, additional regressors should be included in equation (3). Without the appropriate control variables, the regression residuals could display, say, serial correlation. Eichengreen (2007), for example, points out that serial correlation observed in the previous section is suggestive of the omission of variables accounting for internal and external imbalances.

To allow for effects of imbalances, Cheung et al. (2007) extends the model (3) by including a demographic factor (the under 14 and over 65 dependency ratios, ${ }^{16}$ an index of capital account openness, the government deficit, and the M2/GDP ratio (as a proxy for financial deepening) into the list of explanatory variables. They also consider possible effects of corruption to account for China's institutional characteristics. The rationale behind the selection of these additional regressors is that they are found to be factors that significantly influence current account balances. ${ }^{17}$

Here, we re-estimate the multivariate extensions of (3) using the updated dataset. Two different specifications are estimated. The first specification accounts for the marginal effects of 
demographics, policy, and financial development by adding the shares of population under 14 and over 65, the index of capital account openness, the ratio of government deficit to GDP and and the ratio of M2 to GDP to the right hand side of (3). The second specification considers institutional factors and adds capital account openness, index of corruption, and the interaction term of the two variables to (3). See Cheung et al. (2007) for a detailed discussion of these variables and the data sources.

The results are reported in Table 3. Consistent with Cheung et al. (2007), most of the variables indeed exert significant influences on the real exchange rate. While the resulting point estimates of the extent of RMB undervaluation vary somewhat, in no cases are they found to be statistically significant. In Figures 10 and 11, the actual and predicted rates of the RMB are plotted only for limited sample periods due to data constraints.

[Take in Figures 10 and 11 about here]

China's massive trade account surplus is often referred to as irrefutable evidence of substantial RMB undervaluation. More specifically, it is the starkly contrasting trade balance (or imbalance) of the US and China that draw much attention. From a theoretical point of view, the bilateral trade imbalance does not carry much meaning, and it certainly does not qualify for evidence of exchange rate misalignment. Furthermore, even multi-lateral trade imbalance could be a consequence of optimal saving-investment behavior, and thus, it does not automatically signify that the currency needs re-alignment.

Despite these theoretical arguments, however, the debate over the RMB continues to be heavily driven by the US and China's trade figures. Those who focus on the trade imbalance may find the indirect approach implemented above to be insufficient. We, therefore, extend our analysis by adding the trade balance to GDP ratio as an additional regressor to (3). To mitigate 
endogeneity bias, the trade balance variable is lagged by one period.

The estimation results are summarized in Table 4. The misalignment estimates are plotted in Figures 12 and 13. The pooled OLS and random effects results suggest that the lagged trade balance indeed has highly significant positive effects. Taking into account this effect, however, makes little difference in terms of uncertainty surrounding the misalignment calculation. In Figures 12 and 13, the actual RMB rate remains to stay within the one standard error prediction band during the recent decade. Again, we are not able to identify significant evidence of the RMB undervaluation.

\section{[Take Figures 12 and 13 about here]}

\section{Concluding Remarks}

It is a challenging task to pin down the "right" level of the exchange rate. While the extent of the RMB misalignment has been intensely debated, there appears little consensus as for even what constitutes the relevant equilibrium, not to mention how to actually measure it, and where exactly the actual value of the RMB stands.

In this study, we revisit some of the critical issues in the debate, drawing upon Cheung et al. (2007). By exploiting the well-known positive price-income relationship in the Balassa-Samuelson tradition, we discuss implications of the data revisions, and highlight uncertainty surrounding the estimates of the extent of the RMB undervaluation. We also extend the analyses by extending the model beyond the bivariate framework. In particular, the implications of the trade balance are explored.

The main points arising from our empirical exercise and discussion are as follows. First, alternative concepts of equilibrium suggest various approaches to estimating the equilibrium 
exchange rate. Qualified misalignment estimates require inferences to absolute levels of equilibrium exchange rates. It would be futile to quote alternative point estimates of the RMB misalignment without taking into account the underlying conceptual differences.

Second, in the widely-used real exchange rate-per capita income relationship approach, the recent data revision by the World Bank has an enormous implication for the debate. Namely, the previously reported undervaluation estimate of some $50 \%$ is reduced drastically to be approximately $10 \%$ undervaluation. Third, none of these misalignment estimates, irrespective of the data revision, appears significantly different from zero. In taking into account statistical uncertainty of the issue, one should bear in mind that the predictive ability of regression models is always subject to variation of disturbances. In this regard, as of 2007 the RMB has remained well within the one standard error prediction bands, exhibiting no evidence of significant undervaluation. Moreover, that characterization has been the case over the past two decades.

Fourth, extending the model to take into account the effects of trade imbalance and other controls does not alter the conclusion significantly. Regardless of whether trade balance is addressed directly or indirectly, we find the extent of the RMB undervaluation to be statistically insignificant.

Finally, we re-emphasize that our findings should not be interpreted as significant evidence of no RMB undervaluation. Rather, the evidence we report is indicative of the limitations of the models and the data in hands. We also note, however, that the imprecision is not unique to the approach we adopt, even though it is often conveniently ignored. Dunaway et al. (2009), by using the RMB as an example, show that equilibrium real exchange rate estimates by the alternative approaches and models commonly used in the literature exhibit substantial variations of their results in response to small perturbations in model specifications, explanatory 
variable definitions, and sample periods. In other words, inferences regarding currency misalignment are very sensitive to small changes in the way the equilibrium exchange rate is estimated. This finding argues for a great deal of circumspection in the area. 


\section{Acknowledgments}

An earlier version of the manuscript was presented at the "Global imbalance and financial crisis" conference held at the Kansai Institute for Society and Economic Research in Osaka in February 2009. We thank the participants of the conference for helpful comments. Eiji Fujii gratefully acknowledges financial support of the Grant-in-aid for Scientific Research of the JSPS. All errors are solely of the authors'. 


\section{References}

Asian Development Bank, (2007), Purchasing Power Parities and Real Expenditures, Asian Development Bank, Manila, Philippines.

Balassa, B. (1964), “The Purchasing Power Parity Doctrine: A Reappraisal”, Journal of Political Economy, Vol. 72 No. 6, pp. 584-596.

Bahmani-Oskooee, M. and Nasir, A., (2005), "Productivity bias hypothesis and the purchasing power parity: A review article”, Journal of Economic Surveys, Vol. 19 No. 4, pp. 671-696.

Bhagwati, J. N., (1984), “Why are services cheaper in the poor countries?”, Economic Journal, Vol. 94 No. 374, pp. 279-286.

Bosworth, B., (2004), "Valuing the Renminbi”, paper presented at the Tokyo Club Research Meeting, February 9-10.

Cairns, J., (2005), “China: How Undervalued is the CNY?”, IDEAglobal Economic Research (June 27).

Cheung, Y., Chinn, M., and Fujii, E., (2010), “China's Current Account and Exchange Rate”, in Feenstra, R. and Wei, S-J. (Eds.), China's Growing Role in World Trade, The University of Chicago Press, Chicago, IL, pp. 231-271, ,.

Cheung, Y., Chinn, M., and Fujii, E., (2009a), "The Illusion of Precision and the Role of the Renminbi in Regional Integration”, in Hamada, K., Reszat and B., Volz, U. (Eds.), Towards Monetary and Financial Integration in East Asia, Edward Elgar Publishing, Northampton, MA, pp.325-356.

Cheung, Y., Chinn, M., and Fujii, E., (2009b), "Pitfalls in Measuring Exchange Rate Misalignment: The Yuan and Other Currencies”, Open Economies Review, Vol. 20 Iss. 2, 
pp. 183-206.

Cheung, Y., Chinn, M., and Fujii, E., (2007), “The Overvaluation of Renminbi Undervaluation”, Journal of International Money and Finance, Vol. 26 No. 5, pp. 762-785.

Cheung, Y., Chinn, M., and Fujii, E., (2005), Why the Renminbi Might be Overvalued (But Probably Isn’t), University of California, Santa Cruz, CA.

Chinn, M., and Ito, H., (2007), "Current Account Balances, Financial Development and Institutions: Assaying the World 'Saving Glut'”, Journal of International Money and Finance, Vol. 26 No. 4, pp. 546-569.

Chinn, M., and Prasad, E., (2003), "Medium-Term Determinants of Current Accounts in Industrial and Developing Countries: An Empirical Exploration”, Journal of International Economics, Vol. 59 No. 1, pp. 47-76.

Cline, W., and Williamson, J., (2008), "Estimates of the Equilibrium Exchange Rate of the Renminbi: Is There a Consensus and, If Not, Why Not?”, in Goldstein M. and Lardy N. R. (Eds.), Debating China’s Exchange Rate Policy, Peterson Institute for International Economics, Washington, D.C., pp. 131-168.

Coudert, V. and Couharde, C., (2007), "Real equilibrium exchange rate in China: Is the renminbi undervalued?”, Journal of Asian Economics, Vol. 18 No. 4, pp. 568-594.

Das, D. K., (2009), "The Evolution of Renminbi Yuan and the Protracted Debate on its Undervaluation: An Integrated Review”, Journal of Asian Economics, Vol. 20 No. 5, pp. 570-579.

Dunaway, S., Leigh, L., and Li, X., (2009), "How Robust are Estimates of Equilibrium Real Exchange Rates: The Case of China”, Pacific Economic Review, Vol. 14 No. 3, pp. 361-375. 
Dunaway, S. and Li, X., (2005), “Estimating China’s Equilibrium Real Exchange Rate”, IMF Working Paper, WP/05/202, International Monetary Fund, Washington, D.C.

Eichengreen, B., (2007), “Comment on Cheung, Chinn and Fujii, "The Overvaluation of Renminbi Undervaluation””, Journal of International Money and Finance, Vol. 26 No. 5, pp. 786-787.

Elekdag, S. and Lall, S., (2008), “International Statistical Comparison: Global Growth Estimates Trimmed After PPP Revisions,” IMF Survey Magazine, January 8, International Monetary Fund, Washington, D.C.

Fernald, J., Edison, H., and Loungani, P., (1999). "Was China the first domino? Assessing links between China and other Asian economies,” Journal of International Money and Finance, Vol. 18 No. 4, pp. 515-535.

Frankel, J., (2006), “On the Yuan: The Choice between Adjustment under a Fixed Exchange Rate and Adjustment under a Flexible Rate”, CESifo Economic Studies, Vol. 52 No. 2, pp. 246-275.

Funke, M., and Rahn, J., (2005), “Just how undervalued is the Chinese renminbi?”, World Economy, Vol. 28 No. 4, pp. 465-89.

Goldstein, M., (2004), “China and the Renminbi Exchange Rate”, in Bergsten, C. F. and Williamson, J. (Eds.), Dollar Adjustment: How Far? Against What? Special Report No. 17, Institute for International Economics, Washington, D.C.

Goldstein, M. and Lardy, N., (2006), “China’s Exchange Rate Policy Dilemma”, American Economic Review, Vol. 96 No. 2, pp. 422-426.

Hinkle, L.E. and Montiel, P.J., (1999), Exchange Rate Misalignment, Oxford University Press/World Bank, New York, NY. 
International Comparison Program, (2007), “Preliminary Results: Frequently Asked Questions,” mimeo, http://siteresources.worldbank.org/ICPINT/Resources/backgrounder-FAQ.pdf

Kravis, I. B. and Lipsey, R. E., (1983), “Toward an Explanation of National Price Levels”, Princeton Studies in International Finance, No. 52, International Finance Section, Department of Economics, Princeton University, Princeton, NJ.

Marquez, J. and Schindler, J., (2007), “Exchange-rate effects on China's trade”, Review of International Economics, Vol. 15 No. 5, pp. 837-853.

Prasad, E. and Wei, S.-J., (2005), "The Chinese Approach to Capital Inflows: Patterns and Possible Explanations”, NBER Working Paper No. 11306, National Bureau of Economic Research, Cambridge, MA.

Rose, A. and Supaat, S., (2007), “Fertility and the Real Exchange Rate”, NBER Working Paper No. 13263, National Bureau of Economic Research, Cambridge, MA.

Rossi, V., (2005), “Is Revaluation of the Renminbi Good News?”, CESifo Forum 3/2005, pp. 29-36.

Samuelson, P., (1964), “Theoretical Notes on Trade Problems”, Review of Economics and Statistics, Vol. 46 No. 2, pp. 145-154.

Subramanian, A., (2008), “Fact Check, Reality Check? New GDP Data”, Peterson Institute for International Economics, Washington, D.C.

Summers, R. and Heston, A., (1991), "The Penn World Table (Mark 5): An Expanded Set of International Comparisons”, Quarterly Journal of Economics, Vol. 106, pp. 327-68.

Thorbecke W. and Zhang, H, (2009), “The Effect Of Exchange Rate Changes On China's Labour-Intensive Manufacturing Exports”, Pacific Economic Review, Vol. 14 No. 3, pp. 398-409. 
Wang, T., (2004), “Exchange Rate Dynamics”, in Prasad, E. (Ed.), China’s Growth and Integration into the World Economy, Occasional Paper, No. 232, International Monetary Fund, Washington, D.C., pp. 21-28.

Wang, Y., Hui, X., and Soofi, A. S., (2007), “Estimating Renminbi (RMB) Equilibrium Exchange Rate”, Journal of Policy Modeling, Vol. 29 No. 3, pp. 417-429.

Zhang, Z., (2001), “Real Exchange Rate Misalignment in China: An Empirical Investigation”, Journal of Comparative Economics, Vol. 29 Iss. 1, pp. 80-94. 


\section{Figure legends}

Figure 1: Real Chinese exchange rate, in logs (official and “adjusted”) and trends

Figure 2: Real trade weighted value of RMB, in logs, and trend.

Figure 3: The rate of RMB misalignment based on the pre-revision data on the PPP-based per capita income

Figure 4: The rate of RMB misalignment based on the revised (November 2008 version) data on the PPP-based per capita income

Figure 5: The rate of RMB misalignment based on the revised (November 2008 version) data on the USD-based per capita income

Figure 6: The actual and predicted RMB values by pooled OLS estimates on PPP-based per capita income (November 2008 data)

Figure 7: The actual and predicted RMB values by pooled OLS estimates on USD-based per capita income (November 2008 data)

Figure 8: The actual and predicted RMB values by Prais-Winsten estimates on PPP-based per capita income (November 2008 data)

Figure 9: The actual and predicted RMB values by Prais-Winsten estimates on USD-based per capita income (November 2008 data)

Figure 10: The actual and predicted RMB values with the demography and other control variables and PPP-based per capita income (November 2008 data)

Figure 11: The actual and predicted RMB values with the institutional variables and PPP-based per capita income, November 2008 vintage data (November 2008 data)

Figure 12: The actual and predicted RMB values by trade-balance-augmented model estimates on PPP-based per capita income (November 2008 data) 
Figure 13: The actual and predicted RMB values by trade-balance-augmented model estimates on USD-based per capita income (November 2008 data) 
Table 1: Studies of the Equilibrium Exchange Rate of the Renminbi

\begin{tabular}{|c|c|c|c|c|c|}
\hline & $\begin{array}{l}\text { Relative PPP, } \\
\text { Competitiveness }\end{array}$ & $\begin{array}{l}\text { Absolute PPP-Income } \\
\text { Relationship }\end{array}$ & $\begin{array}{l}\text { Balassa-Samuelson } \\
\text { with productivity) }\end{array}$ & BEER/FEER & $\begin{array}{l}\text { Macroeconomic } \\
\text { Balance/External Balance }\end{array}$ \\
\hline Time & Wang (2004) & Bosworth (2004) & Cheung et al. (2005) & Zhang (2001) & Bosworth (2004) \\
\hline \multirow[t]{4}{*}{ Series } & Cheung et al. & & & Wang (2004) & Goldstein (2004) \\
\hline & $(2007)$ & & & Funke \& Rahn (2005) & Goldstein and Lardy \\
\hline & & & & Rossi (2005) & 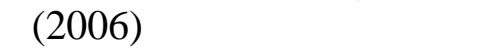 \\
\hline & & & & $\begin{array}{l}\text { Wang, Hui \& Soofi } \\
\text { (2007) }\end{array}$ & Wang (2004) \\
\hline Cross & & Coudert \& Couharde (2007) & & & \\
\hline Section & & Frankel (2006) & & & \\
\hline \multirow[t]{2}{*}{ Panel } & & Cairns (2005) & & Cheung et al. (2007) & Coudert \& Couharde(2007) \\
\hline & & Cheung et al. (2007) & & & \\
\hline
\end{tabular}

Notes: Relative PPP indicates that the real exchange rate is calculated using price or cost indices and that no determinants are accounted for. Absolute PPP indicates the use of comparable price deflators to calculate the real exchange rate. Balassa-Samuelson (with productivity) indicates that the real exchange rate (calculated using price indices) is modeled as a function of sectoral productivity levels. BEER indicates composite models using net foreign assets, relative tradable to nontradable price ratios, trade openness, or other variables. Macroeconomic Balance indicates cases where the equilibrium real exchange rate is implicit in a "normal" current account (or combination of current account and persistent capital inflows, for the External Balance approach). 
Table 2: The Panel Estimation Results of the Baseline Model

\begin{tabular}{|c|c|c|c|c|c|c|c|c|c|c|c|c|}
\hline & \multicolumn{4}{|c|}{ USD-based GDP } & \multicolumn{4}{|c|}{ PPP-based GDP } & \multicolumn{4}{|c|}{ PPP-based GDP (Prais-Winsten) } \\
\hline & $\begin{array}{l}\text { Pooled } \\
\text { OLS }\end{array}$ & Between & $\begin{array}{l}\text { Fixed } \\
\text { effects }\end{array}$ & $\begin{array}{l}\text { Random } \\
\text { effects }\end{array}$ & $\begin{array}{l}\text { Pooled } \\
\text { OLS }\end{array}$ & Between & $\begin{array}{l}\text { Fixed } \\
\text { effects }\end{array}$ & $\begin{array}{l}\text { Random } \\
\text { effects }\end{array}$ & $\begin{array}{l}\text { Pooled } \\
\text { OLS }\end{array}$ & Between & $\begin{array}{l}\text { Fixed } \\
\text { effects }\end{array}$ & $\begin{array}{l}\text { Random } \\
\text { effects }\end{array}$ \\
\hline GDP per & $.173^{* *}$ & $.173^{* *}$ & $.283^{* *}$ & $.209 * *$ & $.183^{* *}$ & $.175 * *$ & $.283 * *$ & $.229 * *$ & $.154^{* *}$ & $.238 * *$ & $.103^{* *}$ & $.137 * *$ \\
\hline capita & $(.013)$ & $(.013)$ & $(.064)$ & $(.010)$ & $(.019)$ & $(.018)$ & $(.064)$ & $(.012)$ & $(.016)$ & $(.017)$ & $(.021)$ & $(.014)$ \\
\hline Constant & $\begin{array}{l}-.157 * * \\
(.040)\end{array}$ & $\begin{array}{l}-.172 * * \\
(.042)\end{array}$ & - & $\begin{array}{l}-.069 * * \\
(.035)\end{array}$ & $\begin{array}{l}-.271 * * \\
(.047)\end{array}$ & $\begin{array}{l}-.307^{* *} \\
(.044)\end{array}$ & - & $\begin{array}{l}-.196 * * \\
(.034)\end{array}$ & $\begin{array}{l}-.022 * * \\
(.003)\end{array}$ & $\begin{array}{l}-.010 * * \\
(.002)\end{array}$ & & $\begin{array}{l}-.024^{* *} \\
(.003)\end{array}$ \\
\hline Adjusted $\mathrm{R}^{2}$ & .379 & .517 & .688 & .379 & .270 & .344 & .687 & .270 & .030 & .536 & .020 & .030 \\
\hline $\begin{array}{l}\text { F-test } \\
\text { Statistic }\end{array}$ & & & $26.572 * *$ & & & & $35.177^{* *}$ & & & & .725 & \\
\hline $\begin{array}{l}\text { Hausman } \\
\text { test statistic }\end{array}$ & & & & $1.317 * *$ & & & & .708 & & & & $4.368 *$ \\
\hline $\begin{array}{l}\text { Number of } \\
\text { observations }\end{array}$ & 4157 & & & & 4169 & & & & 4111 & & & \\
\hline
\end{tabular}

Notes: The data covers 162 countries over the maximum of a twenty eight-years period from 1980 to 2007. The panel is unbalanced due to some missing observations. ${ }^{* *}$ and $*$ indicate $1 \%$ and $5 \%$ levels of significance, respectively. Heteroskedasticity-robust standard errors are given in parentheses underneath coefficient estimates. For the fixed effects models, the F-test statistics are reported for the null hypothesis of the equality of the constants across all countries in the sample. For the random effects models, the Hausman test statistics test for the independence between the time-invariant country-specific effects and the regressor.

The third column labeled (Prais-Winsten) gives estimates from data with serial correlation removed using the Prais-Winsten method. The AR1 coefficient estimate for the Prais-Winsten transformation is 0.939 . 
Table 3: The Panel Estimation Results of the Multivariate Extension Models

\begin{tabular}{|c|c|c|c|c|c|c|c|c|}
\hline & \multicolumn{4}{|c|}{$\begin{array}{l}\text { Demographics, policy, and financial } \\
\text { development }\end{array}$} & \multicolumn{4}{|c|}{ Capital account openness and corruption } \\
\hline & $\begin{array}{l}\text { Pooled } \\
\text { OLS }\end{array}$ & Between & $\begin{array}{l}\text { Fixed } \\
\text { effects } \\
\text { (Within) }\end{array}$ & $\begin{array}{l}\text { Random } \\
\text { effects }\end{array}$ & $\begin{array}{l}\text { Pooled } \\
\text { OLS }\end{array}$ & Between & $\begin{array}{l}\text { Fixed } \\
\text { effects } \\
\text { (Within) }\end{array}$ & $\begin{array}{l}\text { Random } \\
\text { effects }\end{array}$ \\
\hline GDP per & $.090^{* *}$ & $.096^{* *}$ & $.408 * *$ & $.199 * *$ & $.169 * *$ & $.178 * *$ & $.191^{*}$ & $.194 * *$ \\
\hline capita & $(.028)$ & $(.031)$ & $(.085)$ & $(.019)$ & $(.021)$ & $(.023)$ & $(.078)$ & $(.014)$ \\
\hline Population & $.343 * *$ & $.596 * *$ & $.262^{\dagger}$ & $.358 * *$ & & & & \\
\hline under 14 & $(.092)$ & $(.130)$ & $(.141)$ & $(.052)$ & & & & \\
\hline $\begin{array}{l}\text { Population } \\
\text { over } 65\end{array}$ & $\begin{array}{l}.637 * * \\
(.086)\end{array}$ & $\begin{array}{l}.684^{* *} \\
(.140)\end{array}$ & $\begin{array}{l}.371^{\dagger} \\
(.204)\end{array}$ & $\begin{array}{l}.451^{* *} \\
(.075)\end{array}$ & & & & \\
\hline $\begin{array}{l}\text { Capital acct. } \\
\text { openness }\end{array}$ & $\begin{array}{l}.088^{*} \\
(.026)\end{array}$ & $\begin{array}{l}.061 \\
(.054)\end{array}$ & $\begin{array}{l}.108 * * \\
(.036)\end{array}$ & $\begin{array}{l}.107 * * \\
(.013)\end{array}$ & $\begin{array}{l}-.215^{* *} \\
(.071)\end{array}$ & $\begin{array}{l}-.590 * * \\
(.124)\end{array}$ & $\begin{array}{l}.100^{\dagger} \\
(.056)\end{array}$ & $\begin{array}{l}.072^{* *} \\
(.024)\end{array}$ \\
\hline Government & .0001 & -.001 & $.0001^{\dagger}$ & .0001 & & & & \\
\hline deficit & $(.0001)$ & $(.001)$ & $(.0000)$ & $(.0001)$ & & & & \\
\hline M2/GDP & $\begin{array}{l}.421 * * \\
(.072)\end{array}$ & $\begin{array}{l}.752^{* *} \\
(.112)\end{array}$ & $\begin{array}{l}.204 * * \\
(.078)\end{array}$ & $\begin{array}{l}.266^{* *} \\
(.035)\end{array}$ & & & & \\
\hline Corruption & & & & & $\begin{array}{l}.192^{*} \\
(.077)\end{array}$ & $\begin{array}{l}.119 \\
(.107)\end{array}$ & $\begin{array}{l}.034 \\
(.069)\end{array}$ & $\begin{array}{l}.054^{*} \\
(.027)\end{array}$ \\
\hline $\begin{array}{l}\text { Interaction } \\
\text { term }\end{array}$ & & & & & $\begin{array}{l}.422 * * \\
(.089)\end{array}$ & $\begin{array}{l}.905^{* *} \\
(.165)\end{array}$ & $\begin{array}{l}-.056 \\
(.071)\end{array}$ & $\begin{array}{l}-.016 \\
(.031)\end{array}$ \\
\hline Constant & $\begin{array}{l}-1.469 * * \\
(.167)\end{array}$ & $\begin{array}{l}-2.010^{* *} \\
(.268)\end{array}$ & & $\begin{array}{l}-1.141^{* *} \\
(.120)\end{array}$ & $\begin{array}{l}-.466^{* *} \\
(.079)\end{array}$ & $\begin{array}{l}-.440^{* *} \\
(.098)\end{array}$ & & $\begin{array}{l}-.335^{* *} \\
(.041)\end{array}$ \\
\hline $\begin{array}{l}\text { Adjusted } \mathrm{R}^{2} \\
\text { F-test } \\
\text { statistic }\end{array}$ & .542 & .636 & $\begin{array}{l}.779 \\
19.593 * \\
*\end{array}$ & .509 & .471 & .597 & $\begin{array}{l}.780 \\
28.616 * \\
*\end{array}$ & .413 \\
\hline $\begin{array}{l}\text { Hausman } \\
\text { test statistic }\end{array}$ & & & & 7.088 & & & & 1.481 \\
\hline $\begin{array}{l}\text { Number of } \\
\text { obs. }\end{array}$ & 2130 & & & & 2403 & & & \\
\hline \multicolumn{9}{|c|}{$\begin{array}{l}\text { Notes: Under the heading "demographics, policy, and financial development" the sample covers } 123 \\
\text { countries with data available between } 1980 \text { and } 2007 \text {. Under the heading "capital account openness and } \\
\text { corruption," the sample covers } 126 \text { countries with data available between } 1980 \text { and } 2007 \text {. The panel is } \\
\text { unbalanced due to some missing observations. } * *, * \text { and }{ }^{\dagger} \text { indicate } 1 \%, 5 \% \text { and } 10 \% \text { levels of significance, } \\
\text { respectively. Heteroskedasticity-robust standard errors are given in parentheses underneath coefficient } \\
\text { estimates. For the fixed effects models, the F-test statistics are reported for the null hypothesis of the } \\
\text { equality of the constants across all countries in the sample. For the random effects models, the Hausman } \\
\text { test statistics test for the independence between the time-invariant country-specific effects and the } \\
\text { regressors. }\end{array}$} \\
\hline
\end{tabular}


Table 4: The Panel Estimation Results of the Trade-Balance-Augmented Model

\begin{tabular}{|c|c|c|c|c|c|c|c|c|}
\hline & \multicolumn{4}{|c|}{ USD-based GDP } & \multicolumn{4}{|c|}{ PPP-based GDP } \\
\hline & $\begin{array}{l}\text { Pooled } \\
\text { OLS }\end{array}$ & Between & $\begin{array}{l}\text { Fixed } \\
\text { effects } \\
\text { (Within) }\end{array}$ & $\begin{array}{l}\text { Random } \\
\text { effects }\end{array}$ & $\begin{array}{l}\text { Pooled } \\
\text { OLS }\end{array}$ & Between & $\begin{array}{l}\text { Fixed } \\
\text { effects } \\
\text { (Within) }\end{array}$ & $\begin{array}{l}\text { Random } \\
\text { effects }\end{array}$ \\
\hline GDP per capita & $\begin{array}{l}.181 * * \\
(.014)\end{array}$ & $\begin{array}{l}.187 * * \\
(.014)\end{array}$ & $\begin{array}{l}.316^{* *} \\
(.011)\end{array}$ & $\begin{array}{l}.217^{* *} \\
(0.094)\end{array}$ & $\begin{array}{l}.195^{* *} \\
(.020)\end{array}$ & $\begin{array}{l}.191 * * \\
(.022)\end{array}$ & $\begin{array}{l}.317 * * \\
(.061)\end{array}$ & $\begin{array}{l}.243^{* *} \\
(.014)\end{array}$ \\
\hline Trade balance & $\begin{array}{l}.002^{* *} \\
(.000)\end{array}$ & $\begin{array}{l}.003^{\dagger} \\
(.002)\end{array}$ & $\begin{array}{l}.0007 \\
(.0006)\end{array}$ & $\begin{array}{l}.0008^{* *} \\
(.0002)\end{array}$ & $\begin{array}{l}.0018^{*} \\
(.0008)\end{array}$ & $\begin{array}{l}.0027 \\
(.0024)\end{array}$ & $\begin{array}{l}.0007 \\
(.0006)\end{array}$ & $\begin{array}{l}.0008^{* *} \\
(.0002)\end{array}$ \\
\hline Constant & $\begin{array}{l}-.162 * * \\
(.041)\end{array}$ & $\begin{array}{l}-.176^{* *} \\
(.043)\end{array}$ & - & $\begin{array}{l}-.074 * \\
(.037)\end{array}$ & $\begin{array}{l}-.275^{* *} \\
(.048)\end{array}$ & $\begin{array}{l}-.313^{* *} \\
(.046)\end{array}$ & - & $\begin{array}{l}-.196 * * \\
(.036)\end{array}$ \\
\hline $\begin{array}{l}\text { Adjusted } \mathrm{R}^{2} \\
\text { F-test } \\
\text { Statistic }\end{array}$ & .399 & .518 & $\begin{array}{l}.718 \\
26.225^{* *}\end{array}$ & .396 & .287 & .300 & $\begin{array}{l}.718 \\
34.923^{* *}\end{array}$ & .284 \\
\hline $\begin{array}{l}\text { Hausman } \\
\text { test statistic }\end{array}$ & & & & 2.919 & & & & 1.636 \\
\hline $\begin{array}{l}\text { Number of } \\
\text { observations }\end{array}$ & 3571 & & & & 3576 & & & \\
\hline $\begin{array}{l}\text { Notes: The data } \\
\text { unbalanced due } \\
\text { Heteroskedastici } \\
\text { models, the F-te } \\
\text { sample. For the } \\
\text { country-specific }\end{array}$ & $\begin{array}{l}2 \text { countr } \\
\text { hissing } \\
\text { standard } \\
s \text { are rep }\end{array}$ & $\begin{array}{l}\text { over the } \\
\text { ervations. } \\
\text { rors are g } \\
\text { ed for the } \\
\text { ls, the Ha } \\
\text { sor. }\end{array}$ & $\begin{array}{l}\text { aximum of } \\
{ }^{*}, \text { and }^{\dagger} \mathrm{i} \\
\text { en in parer } \\
\text { ull hypoth } \\
\text { man test } \mathrm{s}\end{array}$ & $\begin{array}{l}\text { twenty } \\
\text { dicate } 1 \% \\
\text { neses und } \\
\text { is of the } \\
\text { tistics tes }\end{array}$ & $\begin{array}{l}\text { th-years } \mathrm{p} \\
\% \text { and } 10 \\
\text { leath coe } \\
\text { lality of } \mathrm{t} \\
\text { or the inc }\end{array}$ & $\begin{array}{l}\text { d from } 19 \\
\text { levels of } \\
\text { lent estim } \\
\text { constants } \\
\text { endence b }\end{array}$ & $\begin{array}{l}30 \text { to } 2007 . \\
\text { gnificance, } \\
\text { es. For the } \\
\text { cross all col } \\
\text { ween the ti }\end{array}$ & $\begin{array}{l}\text { The panel } \\
\text { respectivel } \\
\text { fixed effec } \\
\text { ntries in th } \\
\text { ne-invaria }\end{array}$ \\
\hline
\end{tabular}




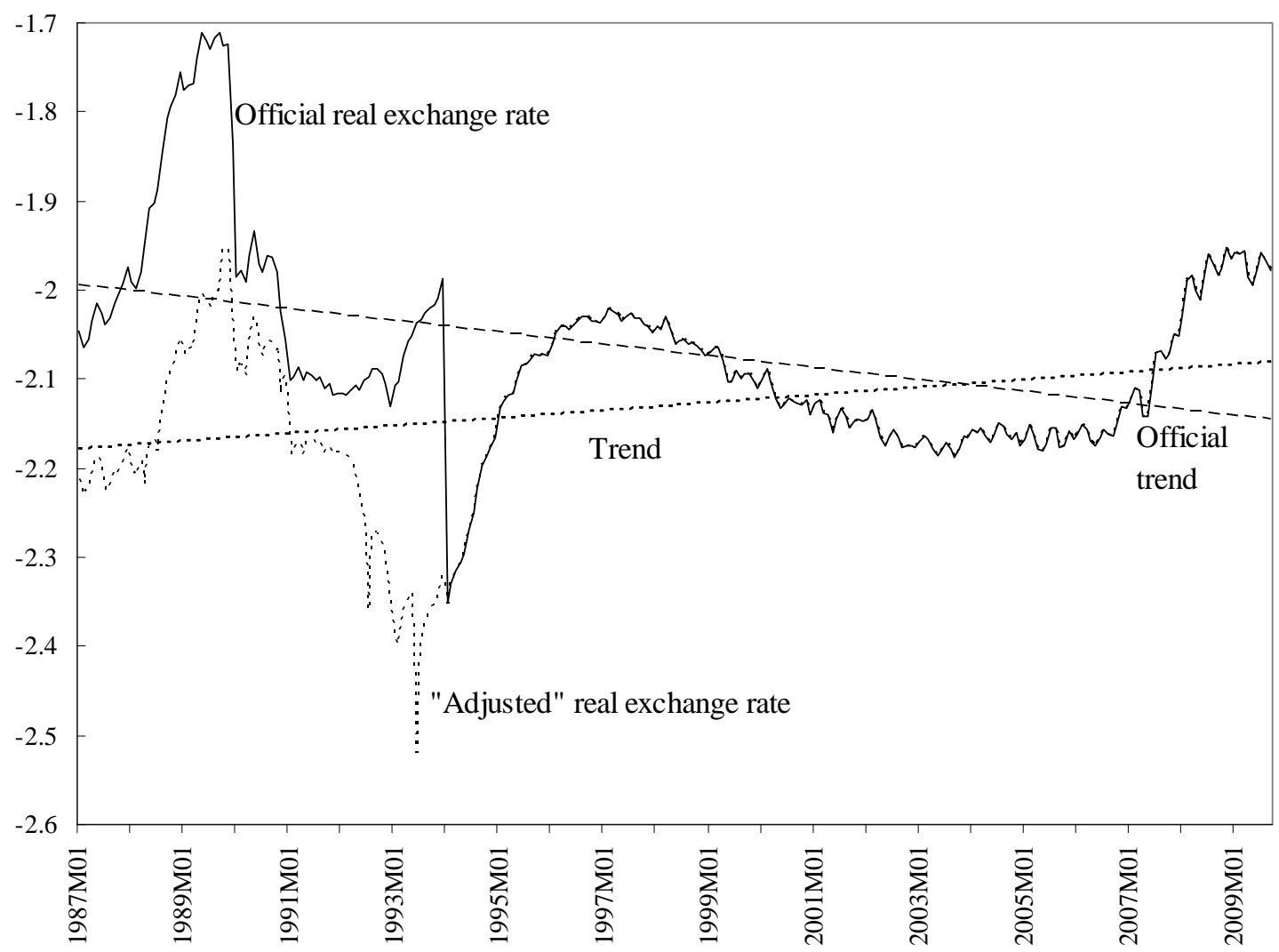

Figure 1: Real Chinese exchange rate, in logs (official and “adjusted”) and trends 


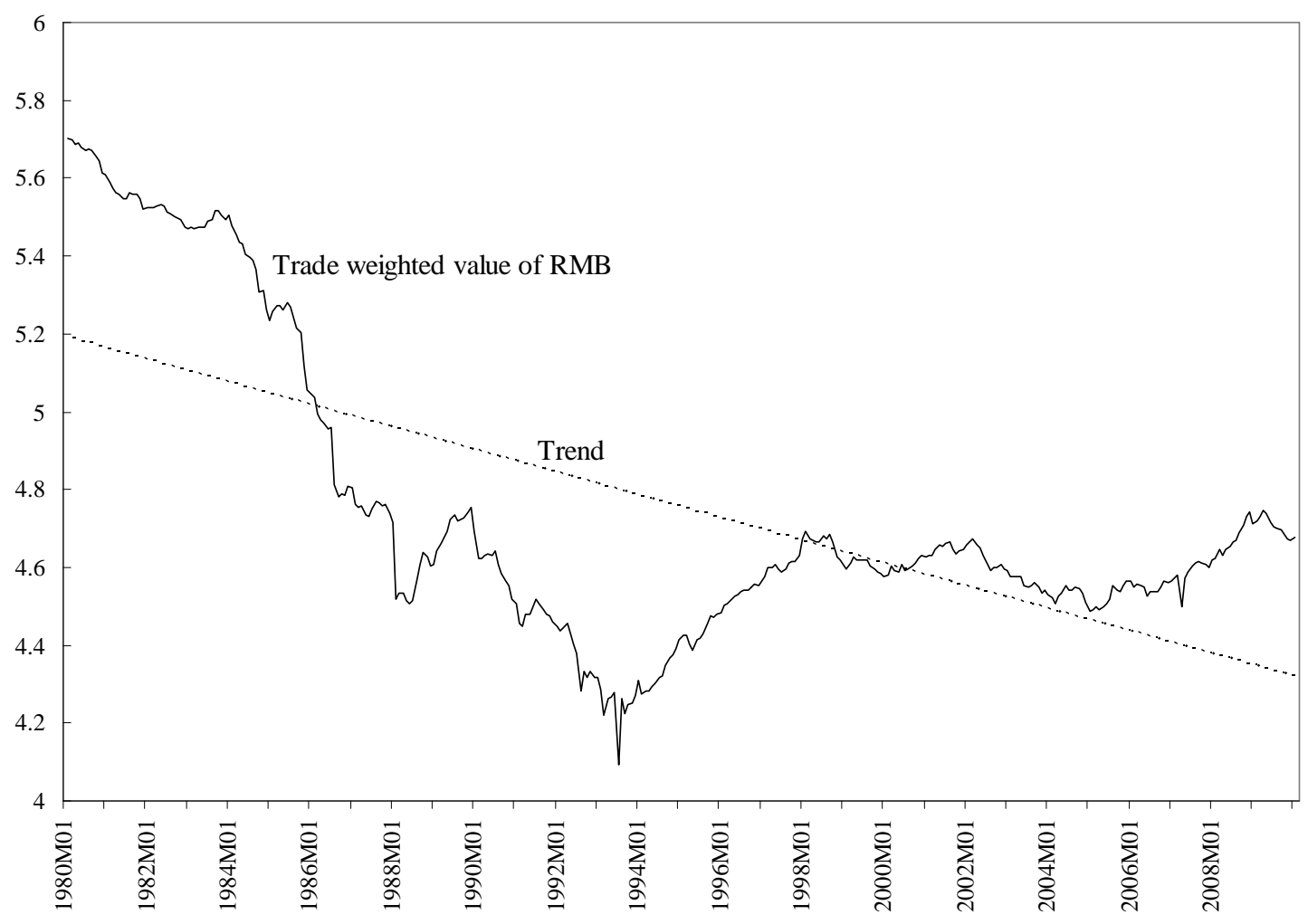

Figure 2: Real trade weighted value of RMB, in logs, and trend. 


\section{Real exchange rate}

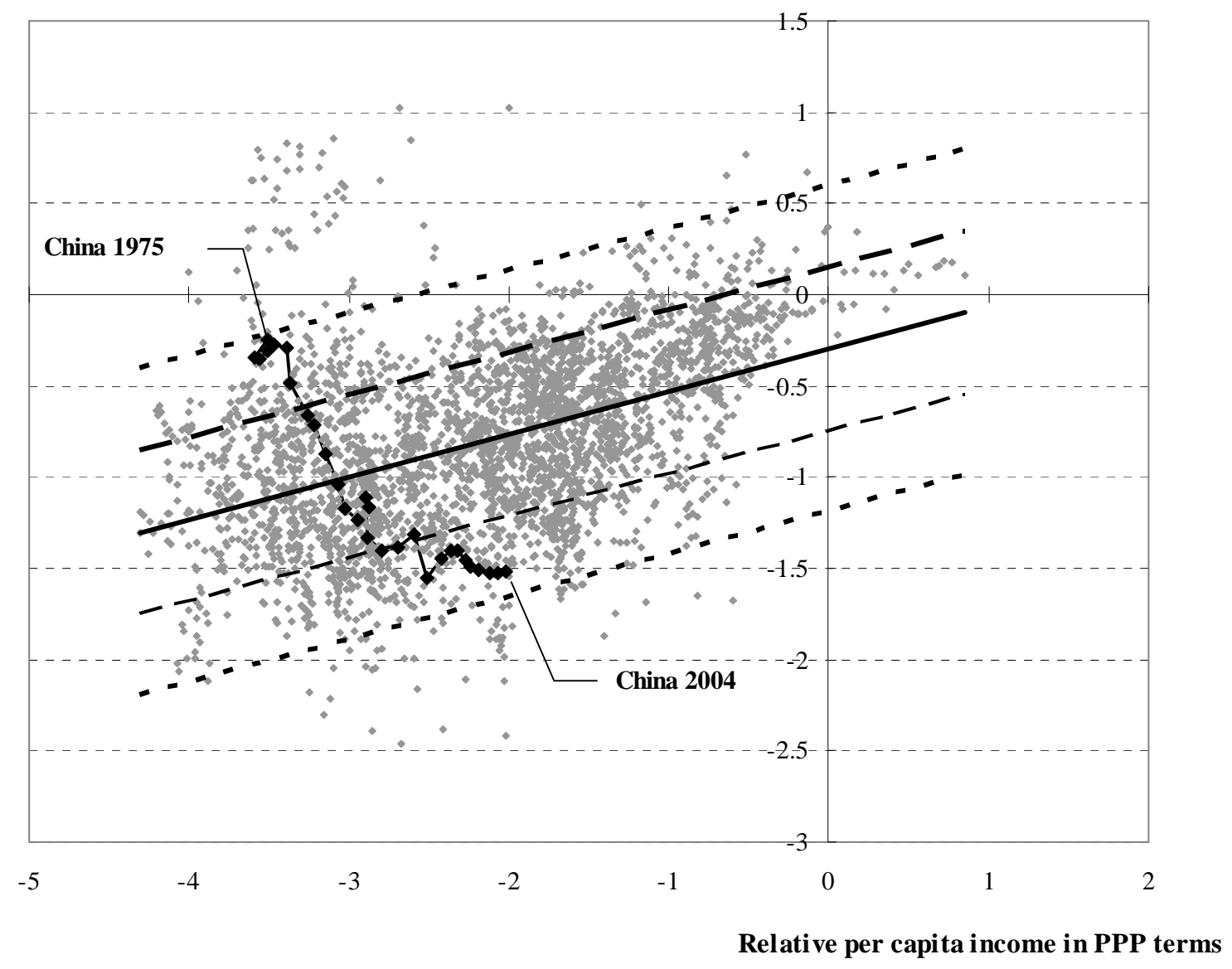

regression line $\_-\ldots \quad 1$ standard error $\ldots$ - - $\quad 2$ standard error

Figure 3: The rate of RMB misalignment based on the pre-revision data on the PPP-based per capita income 


\section{Real exchange rate}

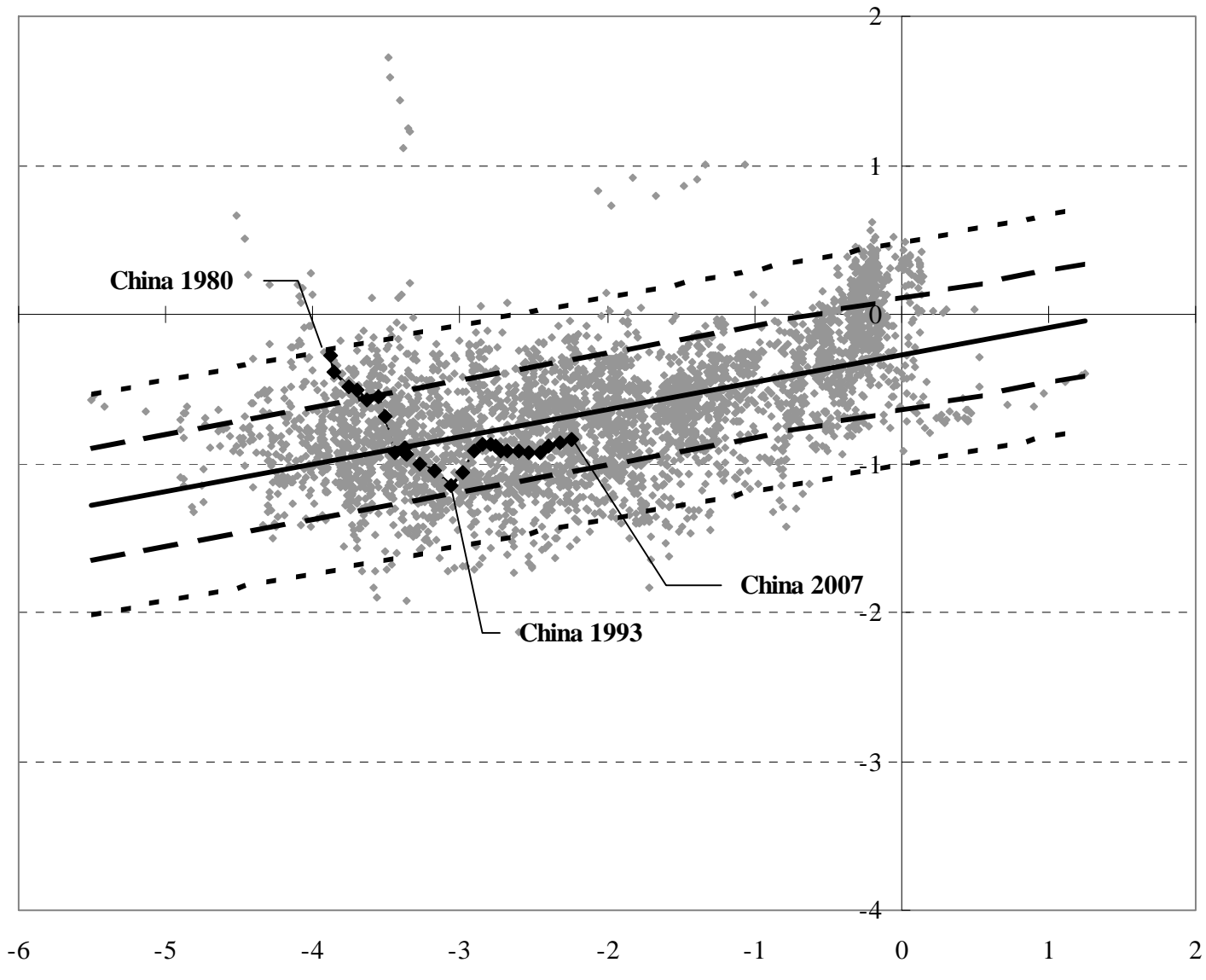

Relative per capita income in PPP terms

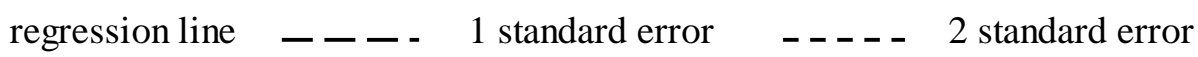

Figure 4: The rate of RMB misalignment based on the revised (November 2008 version) data on the PPP-based per capita income 


\section{Real exchange rate}

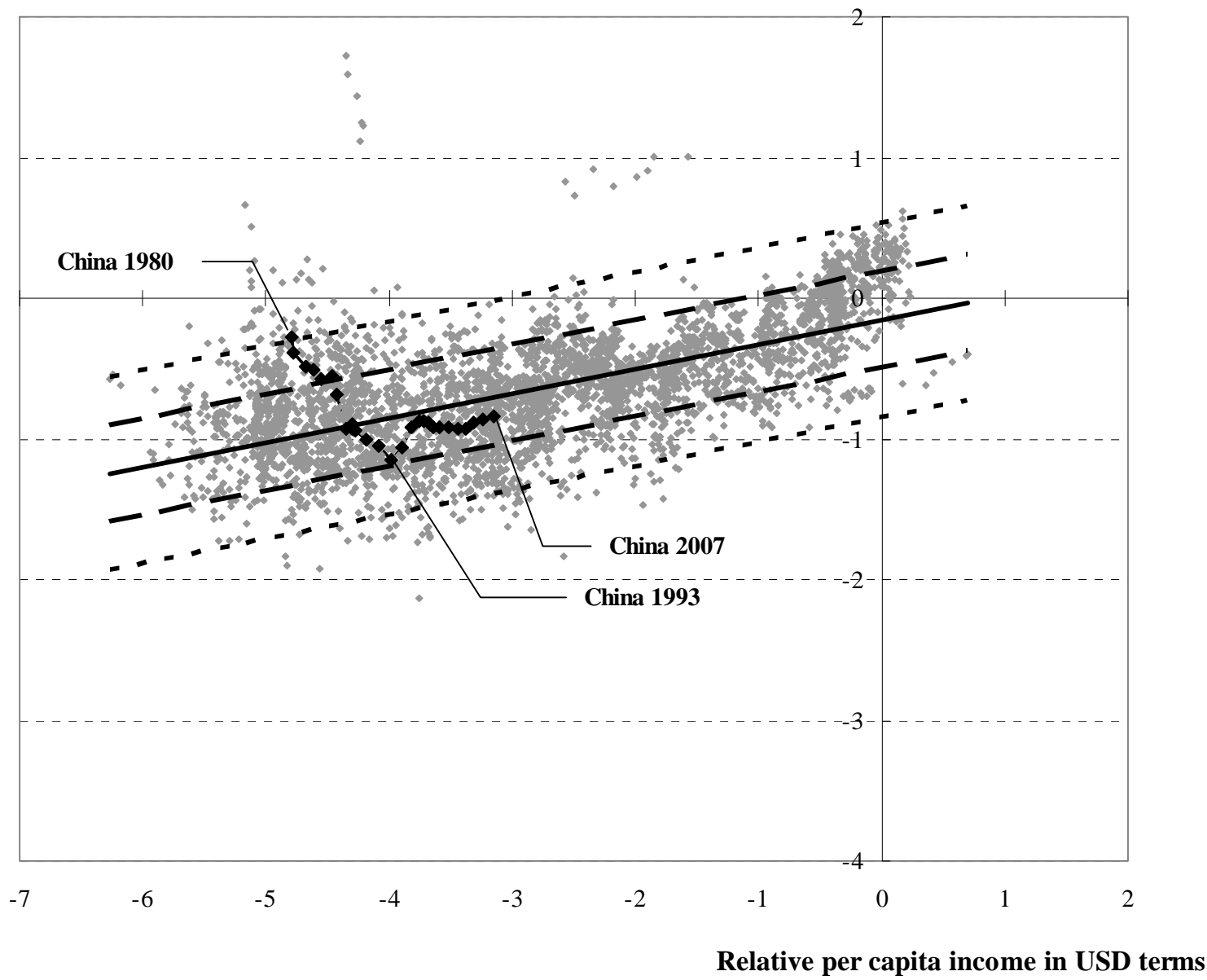

regression line _ _ _ 1 standard error _ _ _ _. 2 standard error

Figure 5: The rate of RMB misalignment based on the revised (November 2008 version) data on the USD-based per capita income 


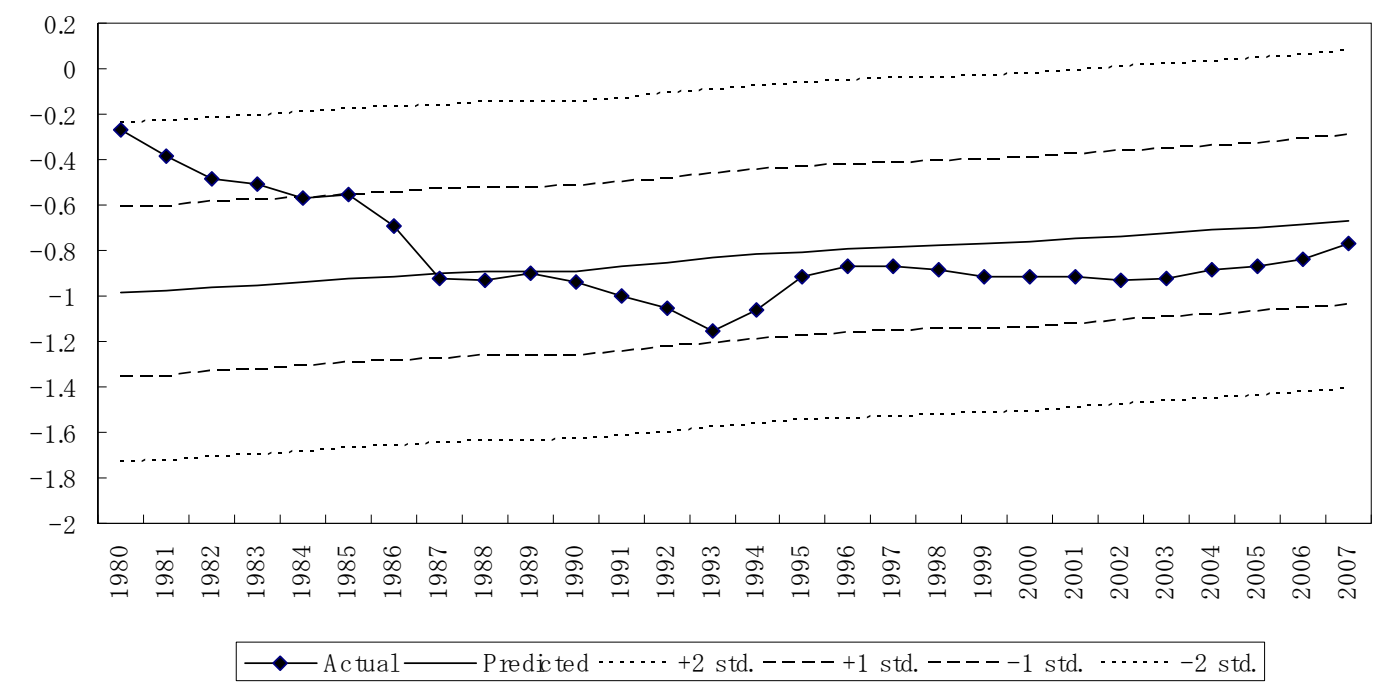

Figure 6: The actual and predicted RMB values by pooled OLS estimates on PPP-based per capita income (November 2008 data)

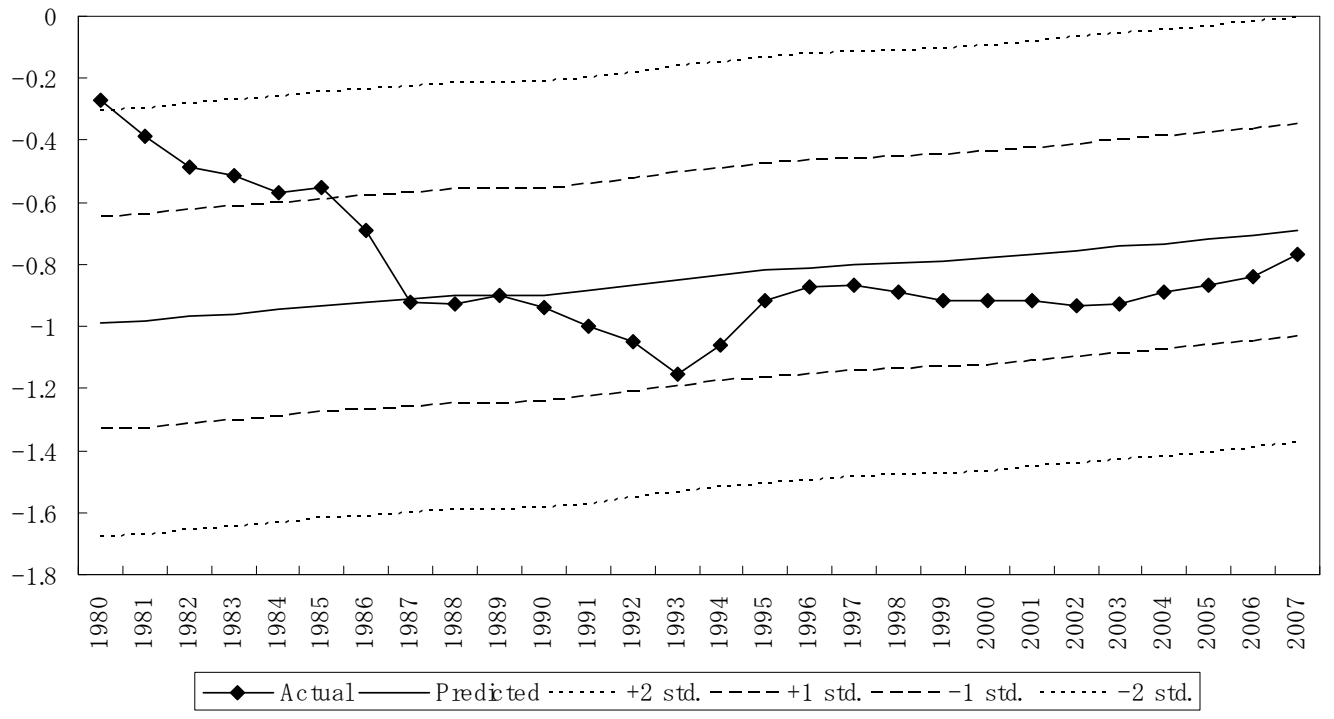

Figure 7: The actual and predicted RMB values by pooled OLS estimates on USD-based per capita income (November 2008 data) 


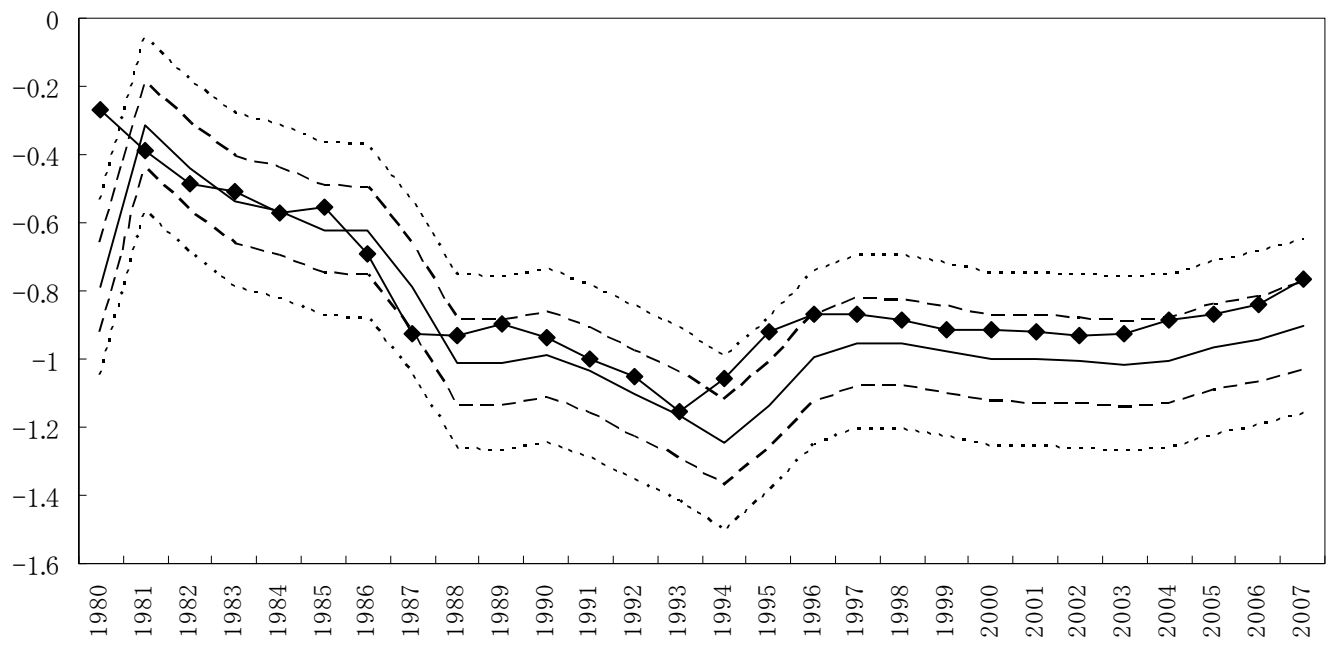

$\longrightarrow$ A ctual $\longrightarrow$ Predic ted $\cdots \cdots+2$ std. ----+1 std. -----1 std. $\cdots \cdots+2$ std.

Figure 8: The actual and predicted RMB values by Prais-Winsten estimates on PPP-based per capita income (November 2008 data)

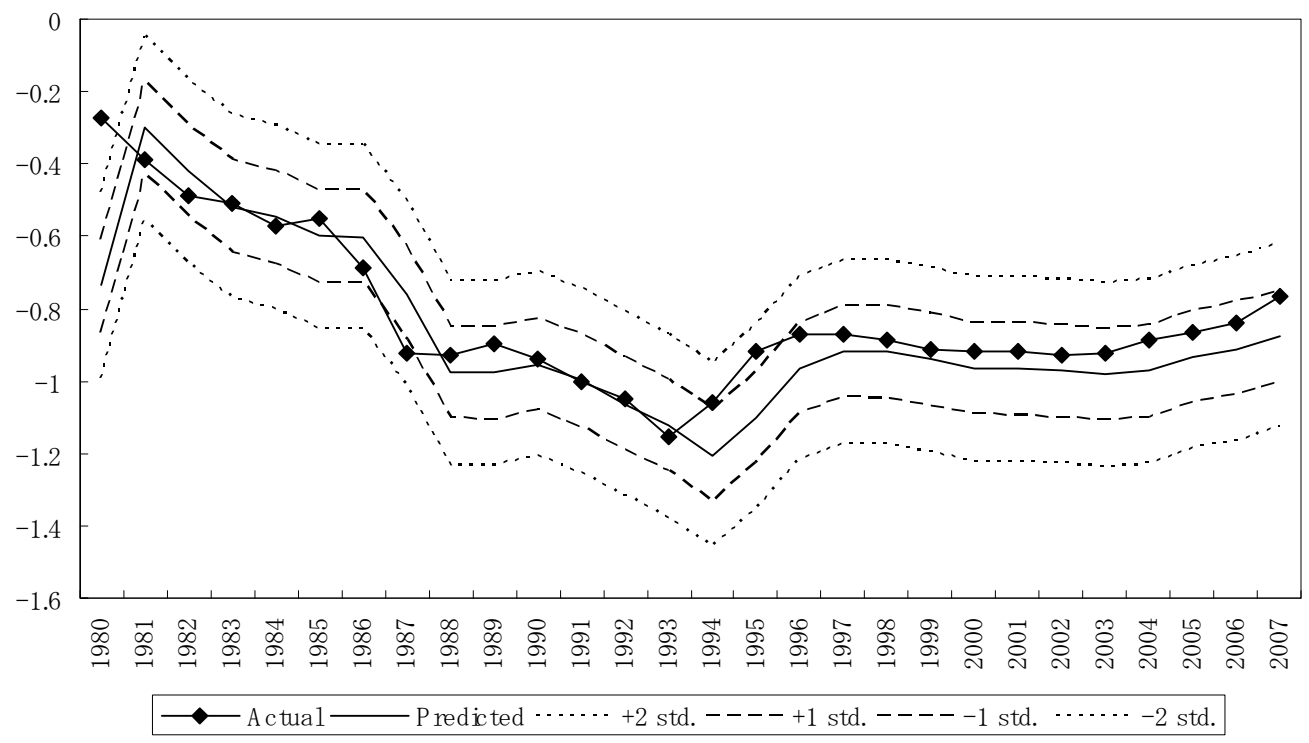

Figure 9: The actual and predicted RMB values by Prais-Winsten estimates on USD-based per capita income (November 2008 data) 


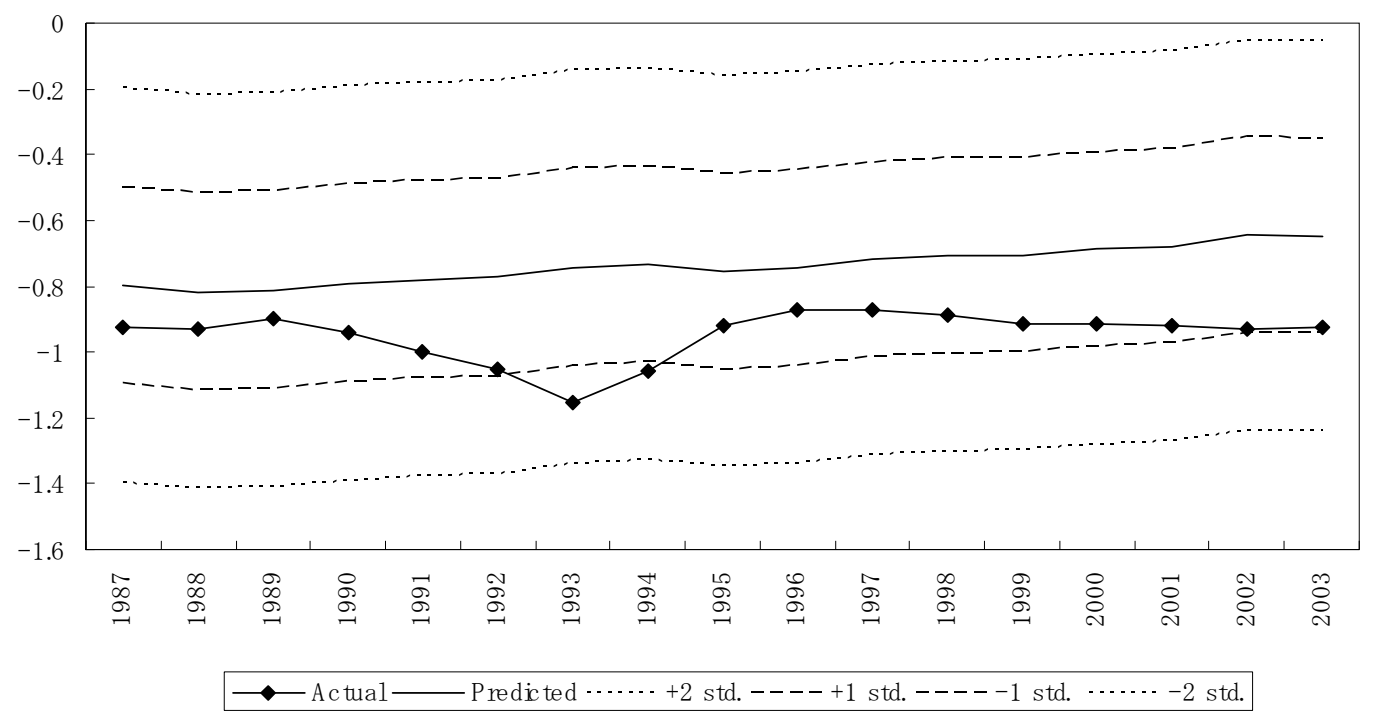

Figure 10: The actual and predicted RMB values with the demography and other control variables and PPP-based per capita income (November 2008 data)

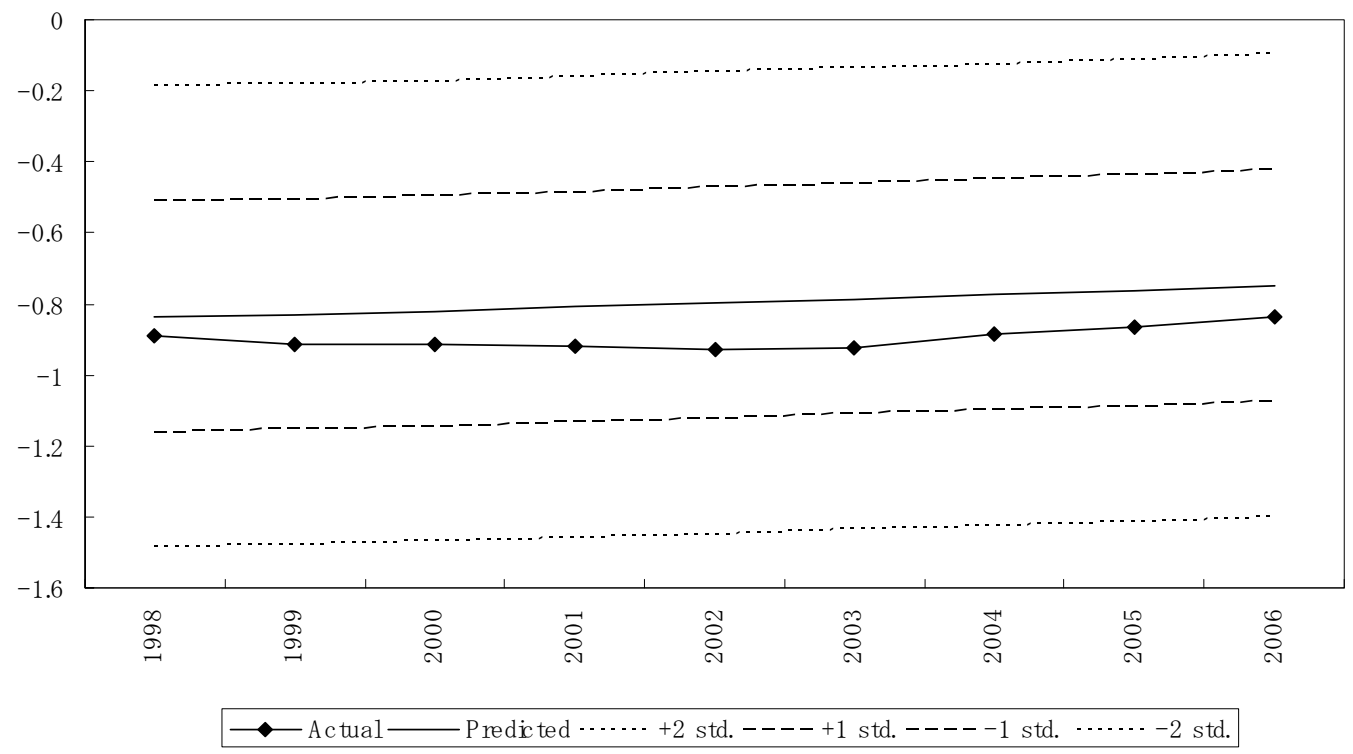

Figure 11: The actual and predicted $R M B$ values with the institutional variables and PPP-based per capita income, November 2008 vintage data (November 2008 data) 


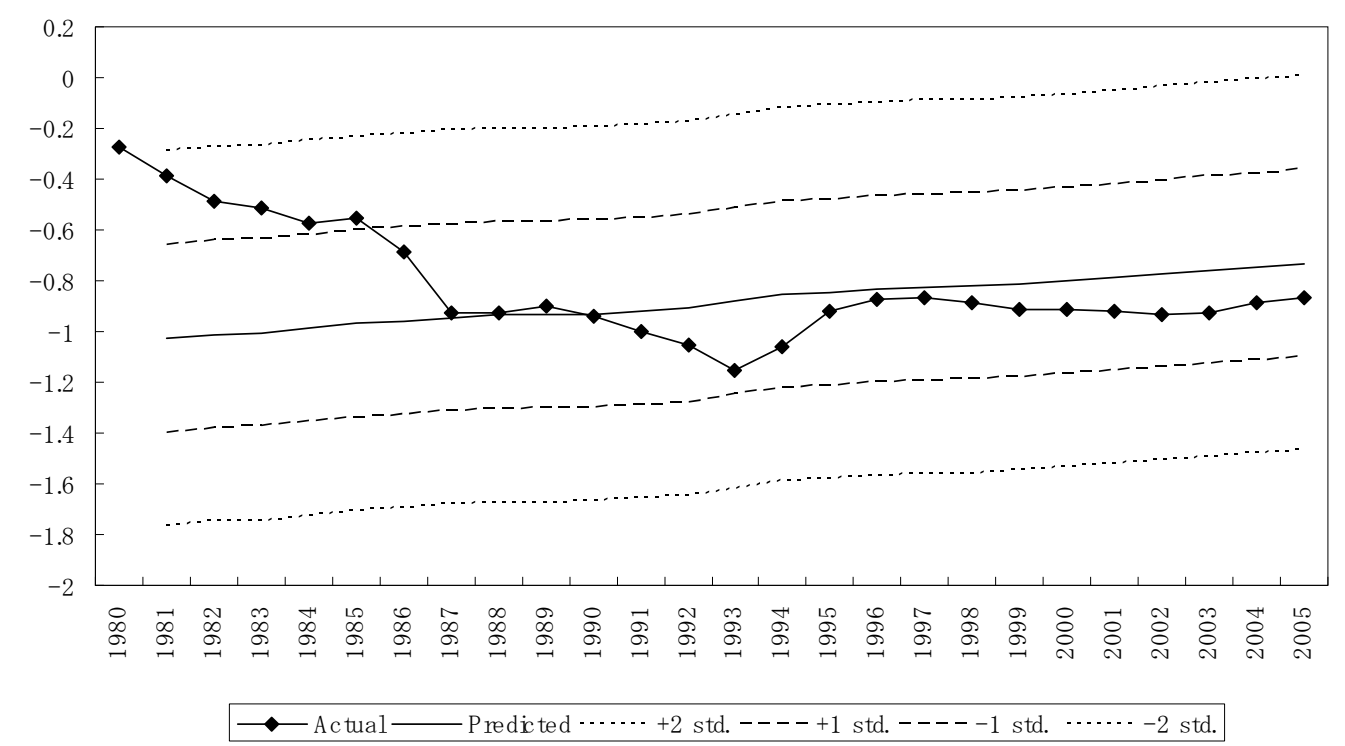

Figure 12: The actual and predicted RMB values by trade-balance-augmented model estimates on PPP-based per capita income (November 2008 data)

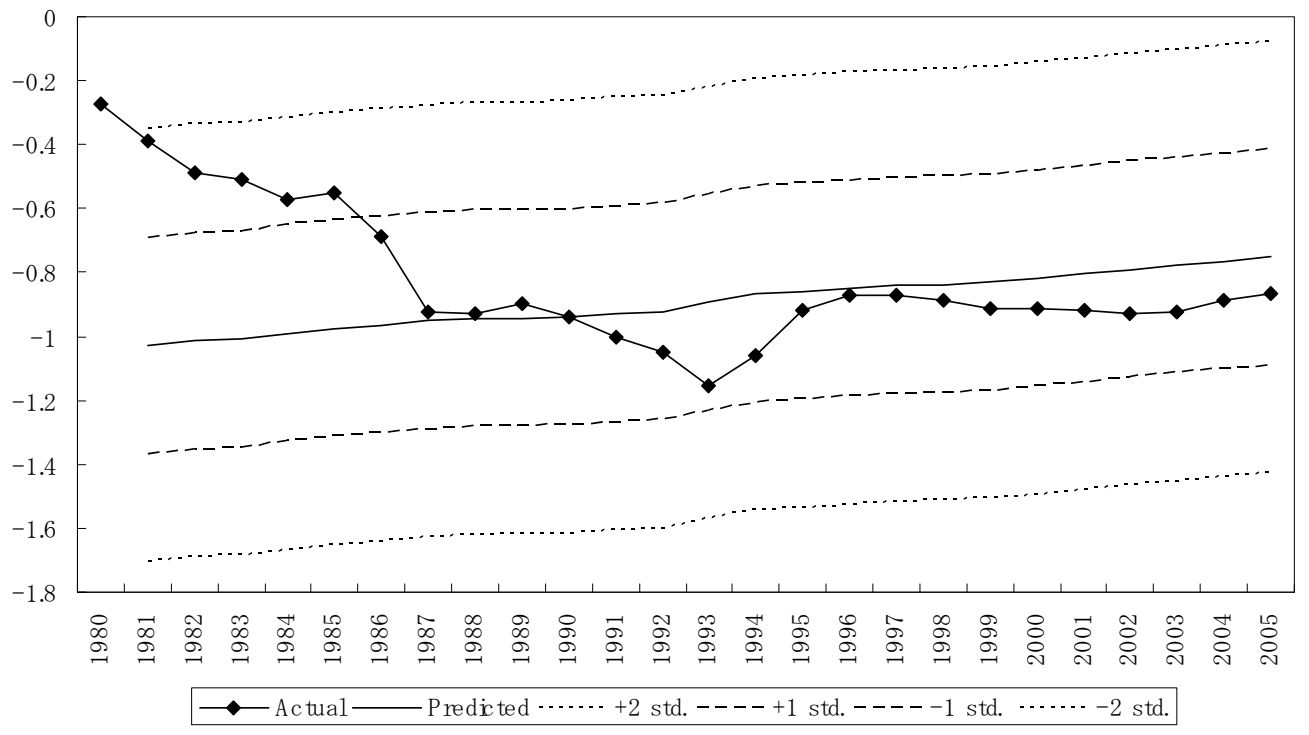

Figure 13: The actual and predicted RMB values by trade-balance-augmented model estimates on USD-based per capita income (November 2008 data) 
$1 \quad$ For a critical assessment of the saving glut argument, see Chinn and Ito (2007).

2 Lori Montgomery and Anthony Faiola, “Geithner Says China Manipulates Its

Currency,” Washington Post (January 23, 2009).

3 Press Conference by International Monetary Fund Managing Director Dominique

Strauss-Kahn with First Deputy Managing Director John Lipsky and External Relations

Director Caroline Atkinson, Istanbul, Turkey, October 2, 2009.

$4 \quad$ On July 21, 2005, China announced a set of reforms on its currency: immediate 2.1 percent appreciation of the RMB against the US dollar; a move from the de facto dollar peg to a adjustable system (i.e. managed float) with reference to a basket of currencies; allowance of fluctuations by 0.3 percent on daily basis. Later on May 15, 2007, the band of daily fluctuation was widened to 0.5 percent.

5 See, for example, Cairns (2005), Cline and Williamson (2008), Das (2009), and Dunaway and Li (2005, 2009).

$6 \quad$ A relevant work is Hinkle and Montiel (1999).

7 The behavioral equilibrium exchange rate models, also known as BEERs, are composites of exchange rate models that incorporate a variety of channels through which the real exchange rate is affected. See, for instance, Zhang (2001), Wang (2004), and Funke and Rahn (2005). Since each author selects different variables to include, the implied misalignments will necessarily vary.

$8 \quad$ See, for instance, Cheung et al. (2010), Marquez and Schindler (2007), and Thorbecke and Zhang (2009) for the data and other issues surrounding China’s trade elasticity estimates.

$9 \quad$ Other prominent explanation for the positive association focuses on the effects of inter-sectoral difference in production factor intensity and international difference in relative 
factor endowments. See Bhagwati (1984) and Kravis and Lipsey (1983).

10 See, for example, Bahmani-Oskooee and Nasir (2005) for a review of empirical studies.

11 The approach is often termed “absolute PPP approach”. However, it is deviations from absolute PPP that the model effectively postulates. In other words, it is the systematic failure of absolute PPP, rather than its validity, that the model purports to. To avoid possible confusion arising from the terminology, we choose to be explicit in terming it the real exchange rate-per capita income relationship approach throughout this paper.

12 Frankel (2006) discusses whether one can speak of an "equilibrium exchange rate" when there is more than one sector to consider.

13 See Asian Development Bank (2007). Also, see Elekdag and Lall (2008) and International Comparison Program (2007) for discussions about the data update program. 14 See Eichengreen (2007) for discussion of the issue.

15 In essence, the Prais-Winsten method is an efficient procedure that incorporates serial correlation into the estimation process. Alternatively, one may consider the Arellano-Bond dynamic panel estimation method that introduces lagged dependent variables into the model to account for serial correlation. The validity of the Arellano-Bond method, however, depends heavily on the use of "good" instruments.

16 See Rose and Supaat (2007) for a discussion. They focus on fertility rate, in their model of the trade weighted exchange rate, as their key demographic variable.

17 See, for instance, Chinn and Prasad (2003) for determinants of current account in the medium run. 